\title{
Hybrid Strategy and Firm Performance: The Moderating Role of Individual and Technological Ambidexterity
}

Ferdinand Mahr

Discussion Paper 2010-4

May 2010

Munich School of Management

University of Munich

Fakultät für Betriebswirtschaft

Ludwig-Maximilians-Universität München

Online at http://epub.ub.uni-muenchen.de/ 


\title{
Hybrid Strategy and Firm Performance: The Moderating Role of Individual and Technological Ambidexterity
}

\author{
Ferdinand Mahr \\ Institute for Communication Economics, Munich School of Management, LMU Munich \\ (f.mahr@Imu.de)
}

May 2010

\begin{abstract}
It is discussed whether hybrid strategies are beneficial or detrimental to a firm's performance, because hybrid strategies lead to organizational tensions that arise from the simultaneous pursuit of distinct strategic activities. However, existing studies on the relationship between hybrid strategy and firm performance have largely neglected the role of the organizational architecture. This study tests the hypothesis that an ambidextrous organizational architecture positively moderates the relationship between a hybrid strategy and firm performance. Particularly, the roles of specific organization structures and HRM practices (individual ambidexterity) and information and communication technologies (technological ambidexterity) are assessed. Further, a hybrid strategy's performance impact is defined in two distinct ways and measured relative to three different comparison groups, that is, the entire sample, no-emphasis strategies, and pure strategies. A novel multi-source dataset on German and Polish manufacturing firms is constructed from three independent sources, including a dataset on objective firm performance indicators. Evidence is found that a hybrid strategy positively impacts firm performance in the presence of organizational ambidexterity, but negatively impacts firm performance in the absence of organizational ambidexterity. These findings are robust across two types of organizational ambidexterity, three different comparison groups, and further robustness tests.
\end{abstract}

Keywords: exploration; exploitation; ambidexterity; hybrid strategy; organizational architecture; firm performance

\section{Acknowledgements}

I am grateful to my $\mathrm{PhD}$ supervisor Tobias Kretschmer for making this research possible. Many thanks to Richard Burton, Harold Doty, and Lorin Hitt for making available details of their surveys on organizational architecture. I am grateful to my interviewer team Fiona Bannert, Karol Englert, Stefan Jelinek, Vanessa Jelinek, Natalia Ojewksa, Andrea Peschl, Bernhard Rösch, Veronika Ruderer, Anja Staudt, and Doris Thalmeier. This research has generously been funded by Deutsche Telekom Stiftung. Any remaining errors are mine. 


\section{INTRODUCTION}

A central concern of strategic management involves the composition of corporate strategy. Strategy scholars suggest that firms must choose their strategy mix from two distinct types of strategic activities, namely, exploration and exploitation. Exploration is targeted at the development of new and unique product market domains, while exploitation is targeted at efficiency and improvements in existing product market domains.

Much discussion has been dedicated to whether the pursuit of a hybrid strategy that combines exploration and exploitation is beneficial or detrimental to a firm's performance. Some scholars argue that hybrid strategies negatively affect firm performance because of the insurmountable organizational tensions that arise from the simultaneous pursuit of exploration and exploitation (Porter, 1980; 1985; 1996). Others argue that these organizational tensions are solvable, and that hybrid strategies have a positive performance effect equal to (Miles and Snow, 1978) or greater than that of pure strategies (Tushman and O’Reilly, 1996), provided that suitable organizational arrangements are in place.

The empirical findings on the relationship between hybrid strategy and performance are diverse and range from a positive effect (Spanos, Zaralis, and Lioukas, 2004; Uotila et al., 2009) to no effect (Kyriakopoulos and Moorman, 2004) to a negative effect (Thornhill and White, 2007). However, these results must be interpreted with caution because studies have largely neglected the role of organizational architecture. Moreover, a hybrid strategy's performance impact is inconsistently defined in these studies. I argue that any analysis of the relationship between hybrid strategy and performance must take into account organizational architecture, as it moderates the impact of hybrid strategies on firm performance. I argue that an ambidextrous organizational architecture is required to manage the tensions resulting from the simultaneous pursuit of exploration and exploitation. I analyze two different ways to achieve organizational ambidexterity. Individual ambidexterity concerns the potential of organizational structures and human resource management (HRM) practices to enable individual employees to pursue both exploratory and exploitative activities. Technological ambidexterity concerns the potential of information and communication technology (ICT) to support the simultaneous pursuit of exploration and 
exploitation. Further, I argue that different definitions of the performance impact of hybrid strategies must be employed to draw meaningful conclusions. The performance impact of hybrid strategies can be evaluated in comparison to all firms or in comparison to firms with a pure strategy, that is, a strategy with a clear emphasis on either exploration or exploitation. Further, firms with a no-emphasis strategy, that is, firms that lack any strategic emphasis, can serve as a reference group.

To test my hypotheses, I employ a novel multi-source dataset. I match data on objective firm performance indicators and on ICT with data on corporate strategy, and organizational architecture. I find that the impact of a hybrid strategy on firm performance is positive in the presence of organizational ambidexterity, while it is negative in the absence of organizational ambidexterity. Further, I find that hybrid strategies outperform the entire sample and no-emphasis strategies in presence of organizational ambidexterity, but that hybrid strategies underperform the entire sample and are equal in performance to no-emphasis strategies in the absence of organizational ambidexterity. Finally, I find that hybrid strategies match the performance of pure strategies in the presence of organizational ambidexterity, but that hybrid strategies underperform pure strategies in the absence of organizational ambidexterity.

This study contributes to theory and practice in several ways. First, by taking into account the moderating effect of organizational architecture, this study is more theoretically grounded than prior empirical studies. Second, by utilizing different definitions of a hybrid strategy's performance effect, the relative advantages and disadvantages of a hybrid are elaborated in more detail than in prior studies. Third, connections between the largely separated literatures on strategy typologies and organizational ambidexterity are explored. Fourth, the potential of ICT in enhancing the performance effects of hybrid strategies is analyzed by introducing the concept of technological ambidexterity.

In the following section, 2, I present the theoretical and empirical background of this study and develop the hypotheses to be tested. In section 3, I describe the methods, data, and measures that are employed. In section 4, I discuss the results. In the final section, 5, I present conclusions for researchers and practitioners as well as directions for future research. 


\section{THEORY AND HYPOTHESES}

\section{Hybrid strategy, organizational architecture, and firm performance in theory}

The right composition of corporate strategy is the central concern of strategy typologies. The typologies of Porter (1980; 1985), Miles and Snow (1978), and March (1991) have received the most attention; together, the three typologies share two broad similarities. The first similarity is the idea that firms have to choose their strategy mix from two distinct strategic emphases. Porter $(1980 ; 1985)$ distinguishes between a differentiation and a cost leadership strategy, while Miles and Snow (1978) distinguish between a prospector and a defender strategy. Finally, March (1991) distinguishes between an exploration and an exploitation strategy. I use March's (1991) terms in the following. The second similarity is that the typologies advance hypotheses regarding the performance outcomes of different strategy mixes.

According to Porter $(1980 ; 1985)$, differentiation and cost leadership strategies each require a total commitment to distinct organizational arrangements, making the pursuit of a hybrid strategy a 'recipe for below-average performance' (Porter, 1985: 16). Firms with a hybrid strategy suffer from a need for a conflicting set of organizational arrangements and are thus 'stuck in the middle' (Porter, 1980: 41). In contrast, Miles and Snow (1978) introduce a hybrid analyzer strategy that 'combines the strengths of both the Prospector and the Defender' (Miles and Snow, 1978: 68). The analyzer strategy demands a 'delicate balance' between distinct organizational structures and processes and a management that is 'continually vigilant' (Miles and Snow, 1978: 68). However, given separate organizational units with different structures and processes for exploration and exploitation, the analyzer strategy is an equal alternative to pure strategies with respect to achieving superior firm performance (Miles and Snow, 1978). March (1991) recognizes that exploration and exploitation require different organizational forms and also that focusing on either exploration or exploitation is only possible at the expense of the other. A pure explorer 'will ordinarily suffer from the fact that it never gains the returns of its knowledge' due to a never-ending sequence of unrewarded search and change, while a pure exploiter 'will ordinarily suffer from obsolescence' due to a reduced responsiveness to environmental changes (Levinthal and March, 1993: 105). Following this insight, Tushman and O'Reilly (1996) state in their ambi- 
dexterity premise that firms capable of simultaneously pursuing exploitation and exploration are more likely to achieve superior performance than firms emphasizing one at the expense of the other' (Raisch and Birkinshaw, 2008: 392). The capability to leverage a hybrid strategy results from setting up an ambidextrous organization that hosts 'multiple contradictory structures, processes, and cultures within the same firm' (Tushman and O'Reilly, 1996: 24). Tushman and O’Reilly (1996) emphasize that it is difficult to manage the organizational tensions between exploration and exploitation. These authors implicitly argue that for firms without suitable organizational arrangements, the performance effects of a hybrid strategy can be negative (He and Wong, 2004).

In summary, the most influential strategy typologies agree that hybrid strategies produce considerable organizational tensions, but differ with regard to the solvability of these tensions.

\section{Hybrid strategy, organizational architecture, and firm performance in empirical studies}

The findings of empirical studies on the hybrid strategy-performance link range from a negative performance impact of hybrid strategies to no significant to a positive impact (Table 1).

INSERT TABLE 1

I argue that these ambiguous results must be interpreted with caution due two reasons.

First, with regard to methodology, the empirical studies outlined above employ different definitions of a hybrid strategy's performance impact. The studies using March's (1991) strategy typology concentrate on whether hybrid strategies positively affect firm performance at all. In contrast, most studies on Porter's $(1980 ; 1985)$ and Miles and Snow's (1978) typologies compare the average performance of firms with a hybrid strategy with the average performance of different comparison groups. Specifically, firms with a hybrid strategy are compared with all firms, that is, the entire sample of firms of the respective study. Further, firms with a hybrid strategy are compared with firms that pursue a no-emphasis strategy or with firms that pursue a pure strategy. These inconsistencies make prior findings hard to compare. 
Second, with regard to theory, the empirical studies largely do not factor in organizational architecture, at least not in a way that is consistent with theory. As outlined above, some strategy typologies suggest that hybrid strategies positively affect firm performance, provided that there are suitable organizational mechanisms to manage the tensions from the simultaneous pursuit of exploration and exploitation (that is, organizational ambidexterity). In contrast, hybrid strategies negatively affect firm performance in the absence of suitable organizational arrangements (He and Wong, 2004). Thus, the effect of hybrid strategies on firm performance is moderated by organizational ambidexterity which affects the strength and direction of the relationship between predictor variable (hybrid strategy) and dependent variable (firm performance). Thus, the many studies that do not consider organizational ambidexterity do not distinguish between the level at which the tension between exploration and exploitation is caused (that is, corporate strategy) and the level at which the conflict is resolved (that is, organizational architecture). Implicitly and counterintuitively, these studies assume that strategies are always supported by the right organizational architecture. ${ }^{1}$ In the few studies that incorporate organizational ambidexterity, the hybrid strategy is seen as a mediator between organizational ambidexterity and firm performance. Thus, organizational ambidexterity is seen as an antecedent of the hybrid strategy, but it is still the hybrid strategy per se that is assumed to lead to superior performance (Gibson and Birkinshaw, 2004; Lubatkin et al., 2006).

\section{Organizational ambidexterity}

How to create an ambidextrous organizational architecture that reconciles the contradictions between exploration and exploitation has been answered in different ways.

\footnotetext{
${ }^{1}$ This is also reflected by the terminology of many studies using March's (1991) typology. There, the term ambidexterity is used to describe a hybrid strategy (Cao et al., 2009; He and Wong, 2004; Thornhill and White, 2007; Uotila et al., 2009; Venkatraman et al., 2007). In contrast, Tushman and O'Reilly (1996) originally use the term exclusively to refer to the organizational arrangements for managing the tensions from a hybrid strategy; that is, to refer to a feature of organizational architecture and an organizational ability rather than to a feature of corporate strategy.
} 
The strategy typologies described above and many other studies in different management research areas explicitly or implicitly make the distinction between exploration and exploitation. ${ }^{2}$ They largely agree on the organizational structures and HRM practices required for both strategy types. Basically, an organic organizational architecture that relies on decentralization and coordination among functions as well as on HRM practices that focus on general skills and subjective performance appraisals are best suited for exploration. In contrast, a mechanistic organizational architecture that relies on centralization, standardization, and monitoring, as well as on HRM practices that focus on specific functional skills and objective performance appraisals, are best suited for exploitation.

The original and most obvious solution to combine these contradictory organizational architectures is the creation of separate organizational units (that is, structural ambidexterity). Hence, individuals in units with an organic architecture focus entirely on exploration, while individuals in units with a mechanistic architecture focus entirely on exploitation (Benner and Tushman, 2003; Duncan, 1976; Miles and Snow, 1978; Tushman and O'Reilly, 1996).

However, recent studies argue that dual structures are difficult to implement and that some firms fail at establishing sufficient linkages between exploratory and exploitative units, leading to the negligence of either exploration or exploitation. Further, it is argued that it is inefficient to let upper management decide on how to divide up the time of employees between exploration and exploitation. Also, it is argued that structural ambidexterity is better suited for larger firms, while smaller firms lack the slack resources and number of hierarchical levels to attain structural ambidexterity (Birkinshaw, 2006; Birkinshaw and Gibson, 2004a; 2004b; 2005; Gibson and Birkinshaw, 2004; Lubatkin et al., 2006).

\section{Individual ambidexterity}

Consequently, an approach other than structural ambidexterity has focused on how organic and mechanistic features can be combined within every organizational unit throughout the firm to

\footnotetext{
2 For example, organization theory (Benner and Tushman, 2003; Burns and Stalker, 1961; Duncan, 1976; Holmqvist, 2004), strategy (Ghemawat and Ricart I Costa, 1993), technology and innovation management (Ambos et al., 2008; He and Wong, 2004), and HRM (Jackson, Schuler, and Rivero, 1989; Schuler and Jackson, 1987; Youndt et al., 1996).
} 
create a behavioral context that enables and encourages individuals to make their own judgments about how to divide their time between exploratory and exploitative activities in the course of their day-to-day work (Adler and Borys, 1996; Adler et al., 1999; Birkinshaw, 2006; Birkinshaw and Gibson, 2004a; 2004b; 2005; Jansen, Van den Bosch, and Volderba, 2005b; Sheremata, 2000). What I call 'individual ambidexterity' 'emerges from choices made by individuals, not from the strategic decisions made by senior executives' (Birkinshaw, 2006). The literature suggests four critical factors to achieve individual ambidexterity, namely, decentralization and standardization, which are structural arrangements, and incentives and skills, which can be attained through certain HRM practices.

Decentralization, that is, the delegation of decision authority to lower hierarchical levels, enables employees to switch between exploratory and exploitative activities in their sole discretion. Employees can pursue their regular production work and at the same time stay alert for new opportunities, generate new ideas, and subsequently experiment with these ideas without seeking permission from above. Decentralization allows employees to directly communicate with employees on the same hierarchical level but from other functions. This allows for an interplay between a variety of perspectives as well as the development of a broad range of skills that are crucial for creativity. Thus, on the one hand, decentralization allows employees to divide up their time between exploration and exploitation in their sole discretion, but on the other hand, it clearly favors exploratory activities. In fact, decentralization may even be detrimental to exploitation. Through decentralization, employees may lose the discipline to efficiently pursue their work. They may invest too much time in imagination and trial and error (Adler et al., 1999; Benner and Tushman, 2003; Birkinshaw, 2006; Birkinshaw and Gibson, 2004a; 2004b; 2005; Gibson and Birkinshaw, 2004; Jansen et al., 2005a; 2006; Raisch et al., 2009; Roberts, 2007; Sheremata, 2000; Tushman and 0’Reilly, 1996).

Thus, the 'specification of clear limits beyond which the individual must no stray' is required (Birkinshaw, 2006). Standardization, that is, the release of oral and written rules and procedures, can guide the efficient execution of exploitative day-to-day activities (Adler and Borys, 1996; Adler et al., 1999; Benner and Tushman, 2003; Jansen, Van den Bosch, and Volderba, 
2006). In addition, standardization can increase the efficiency of exploratory activities without impairing creativity. First, standardization can be used to codify lessons of prior experience with the creation and implementation of exploratory innovations as well as to disseminate these best practices throughout the firm (Adler and Borys, 1996; Adler et al., 1999; Jansen et al., 2005a; Roberts, 2007; Sheremata, 2000). Second, standardization can be used to increase the lateral knowledge exchange needed for creativity and at the same time reduce its costs (Jansen et al., 2005a). Thus, standardization enhances the efficient pursuit of the current product market agenda (exploitation) and also ensures the efficient pursuit of exploratory activities that are targeted at changing the product market agenda.

A further mechanism to make sure that employees balance their exploratory and exploitative activities is to give them incentives for both types of activities through employee appraisal and performance-based pay (Birkinshaw, 2006; Birkinshaw and Gibson, 2004a, 2004b, 2005; Gibson and Birkinshaw, 2004). Exploration requires collaboration among employees as well as the development of a broad range of skills, which are hard to measure objectively. Thus, employee appraisal and performance-based pay should be based on subjective performance measures; that is, on behavior rather than results and on skill development. In contrast, exploitation focuses on efficiency improvement. Thus, individual performance contributions to exploitation can easily be attributed. Consequently, performance appraisal that incentivizes exploitation should be based on objective performance measures, that is, on quantitative results (Jackson et al., 1989; Schuler and Jackson, 1987; Youndt et al., 1996).

Finally, the importance of employee selection and training to enable employees to fulfill exploratory as well as exploitative tasks has been highlighted (Adler et al., 1999; Birkinshaw, 2006; Birkinshaw and Gibson, 2004a, 2004b, 2005; Gibson and Birkinshaw, 2004). To foster exploratory skills, employee selection and training should lay stress on a broad range of skills, including problem-solving skills, skills that allow employees to understand the entire production process, and skills that are usable in a variety of positions in the firm. Finally, skills that foster the exchange of ideas throughout an organization should be advanced (Schuler and Jackson, 1987; Youndt et al., 1996). To foster exploitative skills, employee selection and training should focus 
on firm-, product-, and function-specific skills, the correction of skill deficiencies, and knowledge about the firm's rules and procedures (Delery and Doty, 1996; Schuler and Jackson, 1987; Youndt et al., 1996).

\section{Technological ambidexterity}

Like organizational structures and HRM practices, ICT can also support ambidexterity.

ICT has been suggested as a means to support components of both organic and mechanistic organizational architectures (Dewett and Jones, 2001; George and King, 1991; Huber, 1990; Pinsonneault and Kraemer, 1997), that is, architectures supporting both exploration and exploitation (Benner and Tushman, 2003; Duncan, 1976; Miles and Snow, 1978). Other studies show that ICT directly facilitates the exploratory and exploitative activities of individuals (Kane and Alavi, 2007; Mom, Van den Bosch, and Volderba, 2003). Further studies show that ICT may serve exploratory goals like product innovation and exploitative goals such as cost reduction (Aral and Weill, 2007; Oh and Pinsonneault, 2007). These studies also emphasize that ICT is not a homogenous technology but rather that different types of ICT support different organizational architectures, employee activities, and performance dimensions. Thus, I argue that different ICT types enable exploration (that is, exploratory ICT) and explotiation (that is, exploitative ICT) and that their combination supports ambidexterity.

As groupware applications and corporate intranets facilitate the collaboration of employees, they are examples of exploratory ICT. Groupware applications offer functionalities such as email, instant text messaging, conferencing, document sharing and group scheduling (Ellis, Gibbs, and Rein, 1991; Grudin, 1994). Similarly, corporate intranets are private computing networks internal to an organization that are used to offer groupware applications (Curry and Stancich, 2000; Ginsburg and Duliba, 1997). Thus, groupware applications (Alavi and Leidner, 2001; Dewett and Jones, 2001; Ellis et al., 1991; Kane and Alavi, 2007) and corporate intranets (Bloom et al., 2009; Mom et al., 2003) enable employees to communicate with each other, share information, and work together. As a consequence, groupware applications and corporate intranets facilitate decentralization and thus exploration. 
As enterprise resource planning (ERP) applications and workflow applications facilitate centralization, standardization, and results-based employee appraisal, they are examples of exploitative ICT. Both ERP and workflow applications focus on the automation of business processes and data transfers across the organization (Cardoso, Bostrom, and Sheth, 2004). They integrate information across various functional departments and offer real-time metrics regarding orders, stocks, financials, and other firm characteristics. Hence, a full picture of what is currently happening in an organization and a clear view of the relative performance of different parts of the organization becomes available (Bloom et al., 2009; Cardoso et al., 2004; Chari, Devaraj, and David, 2008; Hendricks, Singhal, and Stratman, 2007; Hitt et al., 2002). Thus, under structural ambidexterity, ERP and workflow applications may foster centralization by giving faster, better, and more information to central decision makers (Bloom et al., 2009; Chari et al., 2008; Hendricks et al., 2007; Stohr and Zhao, 2001). Further, ERP and workflow applications enhance centralization by allowing managers to better monitor the implementation of their decisions. Similarly, under individual ambidexterity, ERP and workflow applications facilitate the monitoring of the implementation of rules and procedures and thus enhance standardization (Alavi and Leidner, 2001; Grant and Higgins, 1991; Orlikowski and Robey, 1991). Further, as 'performance measurement becomes a matter of examining the system log' (Stohr and Zhao, 2001: 291), ERP and workflow applications facilitate employee appraisal and performance-based pay that is using objective performance criteria. ERP and workflow applications thus foster exploitation under structural and individual ambidexterity.

\section{Hypotheses}

I presented the argument that the impact of hybrid strategies on firm performance is positively moderated by organizational ambidexterity.

Hypothesis 1: Organizational ambidexterity positively moderates the impact of hybrid strategies on firm performance. 
I further noted that the performance advantages of hybrid strategies to different comparison groups can be studied. Figure 1 shows the five groups of firms that I distinguish according to the two dimensions of corporate strategy and organizational architecture. ${ }^{3}$

INSERT FIGURE 1

Building on hypothesis 1, I suggest that the average performance of firms with a hybrid strategy and organizational ambidexterity is higher than the average performance of the entire sample of firms in my study. In contrast, the average performance of firms with a hybrid strategy but without organizational ambidexterity is below the average performance of the entire sample of firms (average performance of groups 1 and 2 versus groups 1 to 5).

Hypothesis 2a (2b): On average, in the presence (absence) of organizational ambidexterity, hybrid strategies outperform (underperform) the entire sample of firms.

I further hypothesize that the average performance of firms with a hybrid strategy and organizational ambidexterity is greater than the average performance of firms with a no-emphasis strategy. In contrast, the average performance of firms with a hybrid strategy but without organizational ambidexterity, matches the rather low average performance of the firms that lack a clear strategic emphasis (average performance of groups 1 and 2 versus group 5).

Hypothesis 3a (3b): On average, in the presence (absence) of organizational ambidexterity, hybrid strategies outperform (match) no-emphasis strategies.

Miles and Snow (1978) hypothesize that firms with hybrid strategies and organizational ambidexterity perform as well as firms with pure strategies, while ambidexterity researchers hypothesize that in the long-term firms with hybrid strategies and organizational ambidexterity even outperform firms with pure strategies (Raisch and Birkinshaw, 2008). Due to the composition of the sample used in this study, I advance the hypothesis that in the short-term, firms with a hybr-

\footnotetext{
${ }^{3}$ It makes sense to subclassify the group of firms with a pure strategy into firms with or without pure structures and HRM practices in order to allow for more subtle performance comparisons. It is intuitive to assume that firms with a pure strategy and high levels of pure structures and HRM practices might display a higher average performance than firms with a pure strategy but with low levels of pure structures and HRM practices.
} 
id strategy and with organizational ambidexterity match the average performance of firms with a pure strategy, while firms with a hybrid strategy but without organizational ambidexterity display a lower average performance than firms with a pure strategy (average performance of groups 1 and 2 versus groups 3 and 4).

Hypothesis 4a (4b): On average, in the presence (absence) of organizational ambidexterity, hybrid strategies match (underperform) pure strategies.

\section{METHOD}

\section{Models}

\section{Moderation effects model}

Hypothesis 1 which pertains to the interaction effect of a hybrid strategy and organizational ambidexterity on firm performance, is tested by the moderation effects model 1 :

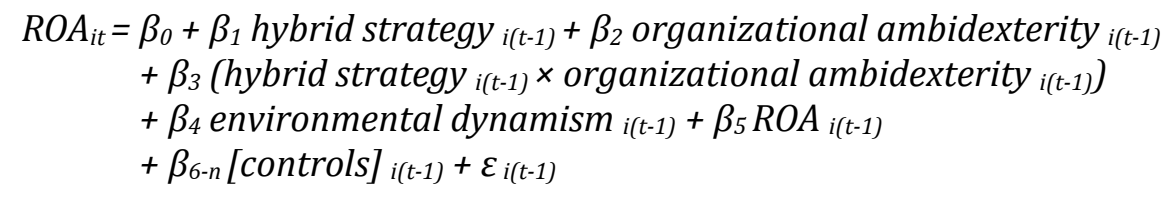

The dependent variable is the return on total assets (ROA) for firm i at time t. The independent variables are hybrid strategy, organizational ambidexterity, the interaction term of strategy and ambidexterity, environmental dynamism, and ROA. Further control variables are described below. To account for repeated observations of the same firm, the error term $\varepsilon$ is clustered by firm; it is Huber-White robust to heteroskedasticity and autocorrelation of unknown form. All independent variables are lagged one year; that is, they appear as at time t-1.

Hypothesis 1 predicts that $\beta_{3}$ is significantly greater than zero, which indicates that the regression of ROA on hybrid strategy depends on the level of organizational ambidexterity.

I include lagged independent variables for theoretical and statistical reasons. First, choosing a strategy and an organizational architecture is linked to long-term investments that might require a certain time period to affect firm performance. Second, instrumenting independent variables by their lagged values mitigates the potential for simultaneity, that is, the possibility that performance and strategy or architecture are jointly determined (Spanos et al., 2004). 
I include environmental dynamism as a control variable, since prior studies have shown that it can affect both a firm's necessity to pursue a hybrid strategy and a firm's success in doing so (Auh and Mengue, 2005; Jansen et al., 2005a; 2006; Raisch and Hotz, 2010).

Consistent with many prior studies on performance, I include the lagged value of the dependent variable as a control to account for any unobserved firm heterogeneity that causes differences in the dependent variable and that is not captured by other controls (Burton, Lauridsen, and Obel, 2002; Spanos et al., 2004; Thornhill and White, 2007; Uotila et al., 2009).

\section{Effects-coding model}

Hypothesis 2 concerns the performance difference between the group of firms with a hybrid strategy and with (or without) organizational ambidexterity as opposed to the entire sample of firms. An effects-coding model is suitable to test this hypothesis, as in an effects-coding model, the coefficient of the indicator variable for a particular group indicates the difference between the mean performance of this group and the mean of the mean performances of all groups, including the respective group (Hardy, 1993; Spanos et al., 2004).4

The effects-coding model 2 includes indicator variables for firms with a hybrid strategy and organizational ambidexterity, for firms with a hybrid strategy but without organizational ambidexterity, for firms with a pure strategy and a pure organizational architecture, and for firms with a pure strategy but without a pure organizational architecture. Firms with a no-emphasis strategy serve as the reference group.

$$
\begin{aligned}
\text { ROA }_{i t}= & \beta_{0}+\beta_{1} \text { hybrid strategy with organizational ambidexterity } i(t-1) \\
& +\beta_{2} \text { hybrid strategy without organizational ambidexterity } i(t-1) \\
& +\beta_{3} \text { pure strategy with pure organizational architecture } i(t-1) \\
& +\beta_{4} \text { pure strategy without pure organizational architecture }{ }_{i(t-1)} \\
& +\beta_{5} \text { environmental dynamism }{ }_{i(t-1)}+\beta_{6} \text { ROA }_{i(t-1)} \\
& +\beta_{7-n}[\text { controls] }]_{i(t-1)}+\varepsilon_{i(t-1)}
\end{aligned}
$$

Hypothesis 2 a predicts that $\beta_{1}$ is significantly greater than zero, which indicates that the average performance of firms with a hybrid strategy and organizational ambidexterity lies above the

\footnotetext{
${ }^{4}$ Although the mean of the means of all groups does not equal the overall mean of the sample if there are unequal numbers of observations in each group, the regression coefficient of a particular group can still be interpreted 'as a measure of the 'eccentricity' or the 'uniqueness' of the specified group in comparison to an 'average' value for the entire sample' (Spanos et al., 2004: 153).
} 
average performance of the entire sample. Hypothesis $2 \mathrm{~b}$ predicts that $\beta_{2}$ is significantly smaller than zero, indicating that the average performance of firms with a hybrid strategy but without organizational ambidexterity lies below the average performance of the entire sample.

\section{Dummy-coding models}

Hypotheses 3 and 4 concern the performance differences between the group of firms with a hybrid strategy and with (or without) organizational ambidexterity as opposed to two different comparison groups. Dummy-coding models are suitable to test these hypotheses.

Hypothesis 3 concerns the performance difference between the group of firms with a hybrid strategy and with (or without) organizational ambidexterity as opposed to the group of firms with a no-emphasis strategy. Thus, the dummy-coding model 3 includes indicator variables for all groups of firms, except for firms with a no-emphasis strategy. Apart from the coding of the indicator variables, model 3 is equal to model 2.

Hypothesis 3a (3b) predicts that $\beta_{1}\left(\beta_{2}\right)$ in model 3 is significantly greater than zero (not significantly different from zero), which indicates that the average performance of firms with a hybrid strategy and with (without) organizational ambidexterity lies above (is equal to) the average performance of firms with a no-emphasis strategy.

Hypothesis 4 concerns the performance difference between the group of firms with a hybrid strategy and with (or without) organizational ambidexterity as opposed to the group of firms with a pure strategy. Dummy-coding model 4 includes indicator variables for all groups of firms, except for the firms with a pure strategy and a pure organizational architecture. The dummycoding model 5 includes indicator variables for all groups of firms, except for the firms with a pure strategy but without a pure organizational architecture. Apart from the coding of the indicator variables and the reference groups, models 4 and 5 are equal to model 2 .

Hypothesis $4 \mathrm{a}(4 \mathrm{~b})$ predicts that $\beta_{1}\left(\beta_{2}\right)$ in models 4 and 5 is not significantly different from zero (significantly smaller than zero), which indicates that the average performance of firms with a hybrid strategy and (without) organizational ambidexterity is equal to (lies below) the average performance of firms with a pure strategy. 


\section{Sample}

I employ a novel multi-source panel dataset on corporate strategy, organizational structure, HRM practices, ICT, and firm performance of 784 German and Polish manufacturing firms. To avoid single-source bias, I construct the dataset from three independent sources: (1) a panel of the ICT types used in firms over the period 2005-2008, (2) a panel of firm performance information over the period 2005-2008, and (2) a 2008 cross-section of corporate strategy, organizational structure, HRM practices, ICT use, and other firm characteristics.

I obtained information on the ICT types employed by firms from Harte-Hanks' CI Technology Database (CITDB) which provides annual information on specific hardware and software types that are used by the establishments of more than 10,000 German and 1,800 Polish firms. HarteHanks states that the firms in the CITDB are largely representative of the entire populations of German and Polish firms.

I derived firm performance information from Bureau Van Dijk's ORBIS database, which provides balance sheets and profit and loss statements based on annual company reports.

All German and Polish firms that maintain at least one manufacturing establishment and that are covered by both the CITDB and ORBIS formed the pool of 2,369 potential respondents to a telephone survey on corporate strategy, organizational structure, HRM practices, ICT use, and other firm characteristics that was conducted in August and September 2008. Nine student research analysts contacted 1,788 firms ${ }^{5}$ and interviewed 784 production managers (or similar managers), representing a response rate of 43.8 percent. The firms of the responding production managers do not significantly differ from the non-responding firms in terms of firm performance (that is, return on total assets), but they are slightly larger. ${ }^{6}$

I chose manufacturing firms in order to concentrate on one questionnaire and thus avoid any bias from differences between corporate strategies, organizational structures, HRM practices, and other firm characteristics that are required for the generation of products versus services.

\footnotetext{
5 The remaining 581 firms were not contacted either because they did not exist anymore, they had no manufacturing establishments in Germany or Poland, no telephone number could be identified, or the interviewers were not able to get in touch with the firms before the end of the project.

${ }^{6}$ This is based on a logistic regression with a binary dependent variable that indicates response.
} 
German and Polish firms were chosen for a practical reason, namely, the availability of native speakers as interviewers. I chose production managers as potential respondents because they are typically in upper middle management and thus are able to deliver insights into corporate strategy as well as organizational structure and HRM practices. Further, through the narrow set of informants, single-informant bias was held relatively constant. The surveyed establishments employed on average 68.5 percent of a firm's total employees, indicating that the obtained measures are largely representative of the firms.

Most of the survey items were derived and adapted from prior studies, as described below. The survey instrument was discussed at length with one production manager and then pretested in interviews with 15 additional production managers. The pretest led to slight adaptations in the survey instrument. The questionnaires for Polish production managers were translated from German into Polish by an accredited translator and then checked by two Polish managers and two Polish research analysts.

Corporate strategy is available from the 2008 cross-section, which is matched with two timeseries datasets that cover the period from 2005 to 2008. As corporate strategy is the key component of this study, two measures are undertaken to avoid any bias from strategy changes between 2005 and 2008. First, respondents were asked to indicate the firm's realized strategy during the last three years rather than the intended strategy which is often not fully realized (Mintzberg, 1978). Second, respondents were asked for strategy changes in the last three years. If a respondent indicated that the corporate strategy had strongly or very strongly changed during this period, all observations of this firm are excluded from the analysis.

Hypotheses 1 to 4 are tested with regard to individual and technological ambidexterity. I created two separate samples for individual and technological ambidexterity to reduce the loss of observations due to missing values to an acceptable level. A sample of 258 (302) firms, with each firm represented by at least one of 457 (502) observations, is available for the analysis of individual (technological) ambidexterity. The firms in both samples do not significantly differ from all other German and Polish manufacturing firms included in the CITDB and ORBIS with 
regard to firm performance, but they are slightly smaller. ${ }^{7}$ The firms in the individual (technological) ambidexterity sample have on average 423 (406) employees.

\section{Measures}

\section{Firm performance}

I measure firm performance as the return on total assets (ROA), which is one of the most widelyused firm performance measures in analyses of corporate strategy and organizational architecture (Burton et al., 2002). I obtain ROA from ORBIS and calculate it as (profit or loss before taxation / total assets) $\times 100$.

\section{Corporate strategy}

Measures for the extents to which an exploration strategy and an exploitation strategy are pursued are obtained from my survey on production managers. Respondents were asked to indicate on a Likert scale from 1 ('I do not agree at all') to 5 ('I strongly agree') if several items have been a key part of the respective firm's strategy during the last three years. I derived and adapted all items from prior surveys on strategy typologies or ambidexterity (Dess and Davis, 1984; Doty, Glick, and Huber, 1993; He and Wong, 2004; Kotha and Vadlamani, 1995; Lubatkin et al., 2006; Miller and Toulouse, 1998; Segev, 1989). The items that measure exploration focus on the exploration of new and unique product market domains, while the items that measure exploitation focus on efficiency and improvement in existing product market domains. The exploratory and exploitative items load on different factors in a joint exploratory factor analysis with varimax rotation. Factor loadings are above .53 with cross-loading below .34 . Thus, I use the average of the exploratory items to create a measure of exploration. Further, I use the average of the exploitative items to create a measure of exploitation. Cronbach's alpha for both measures is .76 and thus above the cut-off point of .70 (Nunally, 1978).

\footnotetext{
7 This is based on a logistic regression with a binary dependent variable indicating sample inclusion and notably unproblematic, however, as I am especially interested in the moderating role of individual ambidexterity, which is seen as the appropriate form of organizational ambidexterity for smaller firms (Gibson and Birkinshaw, 2004; Raisch and Birkinshaw, 2008).
} 
Measures for a hybrid strategy have been constructed by multiplying (Gibson and Birkinshaw, 2004; Venkatraman et al., 2007), dividing (Uotila et al., 2009), subtracting (He and Wong, 2004; Cao et al., 2009), and adding (Jansen et al., 2009; Lubatkin et al., 2006) measures for exploration and exploitation. Interacting exploration and exploitation incorporates the assumption that both are complementary, that is, mutually reinforcing. In contrast, consistent with the outlined strategy typologies, I believe that exploration and exploitation are fundamentally different activities that even require separate or complex organizational arrangements in order to be combined within one firm. Dividing and subtracting exploration and exploitation is based on the idea that emphasizing either exploration or exploitation is only possible at the expense of the other. Though this perspective is valid, achieving a balance between exploration and exploitation is fine-tuning. In the first instance, a hybrid strategy requires that both exploration and exploitation are pursued to a sufficiently high degree. I interpret exploration and exploitation as orthogonal activities (Gupta et al., 2006). A firm can engage in high levels of both activities at the same time, provided that suitable organizational arrangements are in place. Further, two studies have shown that an additive approach has had greater explanatory power than the other perspectives (Jansen et al., 2009; Lubatkin et al., 2006). Consequently, to test hypothesis 1, I choose the additive model and measure hybrid strategy as the average of exploration and exploitation. ${ }^{8}$

\section{Individual ambidexterity}

Measures for individual ambidexterity are obtained from my survey on production managers.

Decentralization is measured as the average of the degree of decentralization of various organizational decision rights, ranging from lower-level decisions such as the pace of the work of production workers to higher-level decisions such as product pricing $(\alpha=.88)$. I derived and adapted all items from several prior studies on decentralization (Andersen and Jonsson, 2006; Bloom, Sadun, and Van Reenen, 2009a; Burton et al., 2002; Colombo, Delmastro, and Rabbiosi, 2007; Hanks et al., 1993; Lee and Grover, 2000; Nahm, Vonderembse, and Koufteros, 2003; Pugh, 1973). For each decision right, the respondents were asked to indicate the hierarchical

${ }^{8}$ I employ two robustness tests to mitigate the potential of bias from the additive model, as described below. 
level that is responsible for the decision. As many firms have different numbers of hierarchical levels, the respondents were asked to indicate the total number of hierarchical levels in their firm. Subsequently, every item was standardized so that 0 means that the decision is made at the highest hierarchical level of the firm (that is, fully centralized) and 1 means that the decision is made at the lowest hierarchical level of the firm (that is, fully decentralized).

Standardization is measured as the average of two five-point Likert scale items that are derived and adapted from prior studies $(\alpha=.56)$ (Andersen and Jonsson, 2006; Burton et al., 2002; Hanks et al., 1993; Nahm et al., 2003). Respondents were asked to indicate how many written or oral rules and procedures are in place in their firm.

Employee appraisal, screening, and training are measured by an innovative interview method that is adapted from Bloom, Kretschmer, and Van Reenen (forthcoming). The method incorporates open questions and open answers, which are then transformed into numeric values from 1 to 5 by the interviewer. This method allows for much more detailed insights into HRM practices than is possible with rather short Likert scale items. Further, as respondents do not choose from a predefined set of answers, the method mitigates the problem of social desirability which is important in the context of HRM practices. ${ }^{9}$ For example, some respondents might give unrealistically optimistic answers to questions about the amount or contents of employee training if they feel that these HRM practices are generally considered 'good.' The interviewers were provided with prepared questions; they began with general questions and continued with more specific questions based on the prior answers of respondents. The interviewers were also encouraged to deviate from the prepared questions if needed. Thus, a conversation led by the interviewer took place regarding every HRM practice. The dialog was not ended until the interviewer felt that she or he had a full picture of the HRM practice in question and was able to decide on a numeric score. In particular, the interviewers were asked to indicate on a scale from 1 ('not important at all') to 5 ('very important') the importance of both the exploratory and the

\footnotetext{
9 The Human Subjects Committee of Stanford University approved this methodology for the study of Bloom and Van Reenen (2007), because the respondents' unawareness of being scored is necessary to reduce the problem of social desirability, not risky for the respondents and their employers due to data confidentiality, and temporary as the respondents are debriefed after the end of the project.
} 
exploitative components with respect to employee appraisal, screening, and training. Thus, six measures were generated, namely, three regarding the importance of exploratory components in employee appraisal, screening, and training and three regarding the importance of exploitative components in employee appraisal, screening, and training. The survey instruments for HRM practices were developed specifically for this study but nevertheless share broad similarities with prior studies on HRM practices that are appropriate for different corporate strategies (Jackson et al., 1989; Schuler and Jackson, 1987; Youndt et al., 1996). To test the inter-rater reliability of this survey method, a second interviewer listened to 31.3 percent of all production manager interviews (that is, 245 interviews) and assigned scores to the respondent answers independently from the first interviewer. The correlation coefficients of the first interviewer and the second interviewer scorings for the six HRM variables created using this interview method range from 0.6292 to 0.8088 and were highly significant. This result implies that the survey method leads to relatively homogenous results, even if different interviewers score the same interview. I use the average of the decentralization measure and the three measures for the exploratory components of HRM practices to create a measure for exploratory structures and HRM practices. I use the average of the standardization measure and the three measures for the exploitative components of HRM practices to create a measure for exploitative structures and HRM practices. Finally, I compute individual ambidexterity as (exploratory structures and HRM practices + exploitative structures and HRM practices) / 2.

Alpha reliabilities for the decentralization and standardization measures are provided above. Tests for the internal consistency of the measures for exploratory and exploitative structures and HRM practices and individual ambidexterity are not appropriate, as these measures are designed to capture different aspects of a construct rather than multiple measures of a construct. Thus, there are no specific expectations about the intercorrelations between the aspects; they might correlate positively, negatively, or not at all (Aral and Weill, 2007, Diamantopoulus, Riefler, and Roth, 2008, Jarvis, MacKenzie, and Podsakoff, 2003). 


\section{Technological ambidexterity}

All measures for technological ambidexterity are obtained from the CITDB. The CITDB provides binary variables that indicate if specific hardware and software products are used in the observed establishments. For example, the CITDB would indicate if Exchange Server from Microsoft or Lotus Domino from IBM are in place in an establishment. Harte-Hanks groups these products into broader classes of hardware and software products. For example, Exchange Server and Lotus Domino, which are both collaboration software products, would be assigned to the groupware class. I use these groupings to obtain measures for the four ICT types that are outlined above (see Table 1$) \cdot{ }^{10}$

INSERT TABLE 2

For example, I create a corporate intranet dummy that is coded 1 if any frame-relay, leased-line, or wide-area network is in place in an establishment, as these hardware types are typically employed for intranets (Bloom et al., 2009). Subsequently, the average of the corporate intranet and groupware dummies is used to create an exploratory ICT variable. The average of the ERP and workflow application dummies is used to create an exploitative ICT variable.

\section{Group indicator variables}

To create effects-coded and dummy-coded group indicator variables, I assign all firms in both samples to one group; I employ the two dimensions of corporate strategy and organizational architecture to differentiate between the groups. Consistent with other studies, I use the median-cutoff criterion to assign the firms to groups (He and Wong, 2004). ${ }^{11}$

\footnotetext{
${ }^{10}$ As all information in the CITDB pertains to the establishment-level, I aggregate the four dummies to the firm-level. For example, if any of the observed establishments of a firm possesses a groupware application, the firm-level groupware dummy is coded 1. Note that the establishments surveyed by Harte-Hanks employed on average 85.6 (85.2) percent of a firm's total employees in the individual (technological) ambidexterity sample, indicating that the obtained measures are largely representative of the firms.

11 In the individual ambidexterity sample, I assign a firm to the group of firms with a hybrid strategy and organizational ambidexterity if (1) the firm's value for the exploration measure is equal to or greater than the median of the exploration measure; (2) the firm's value for the exploitation measure is equal to or greater than the median of the exploitation measure; (3) the firm's value for the measure for exploratory structures and HRM practices is equal to or greater than the median of this measure; and (4) the firm's value for the measure for exploitative structures and HRM practices is equal to or greater than the median
} 
INSERT TABLE 3

\section{Control variables}

The measure for environmental dynamism is obtained from my survey on production managers and constructed in the style of two prior studies (Daft, Sormunen, and Parks., 1988; May, Stewart, and Sweo, 2000). Respondents were asked to indicate on scales from 1 to 5 the rate of change, predictability, and importance of seven areas of the environment (market, competitors, technology, labor market, capital market, legislators/regulators, and the socio-cultural environment). I then calculated the dynamism in each of the seven environmental areas as (rate of change + predictability) $\times$ importance and used the average of the seven resulting dynamism variables to create a measure of the overall environmental dynamism $(\alpha=.74) .{ }^{12}$

Firm-level control variables are firm size, measured as total number of employees, and firm age, measured as years in operation. Both measures have been associated with inertia and several other effects that may impact firm performance, corporate strategy, or organizational architecture (He and Wong, 2004; Lubatkin et al., 2006; Spanos et al., 2004). The measures are obtained from ORBIS and log-normalized to compensate for skewness. Further, a dummy variable to account for the firm's nationality is included in all analyses.

of this measure. In contrast, a firm is assigned to the group of firms with a hybrid strategy but without organizational architecture if (1) and (2) apply but if either (3) or (4) or both do not apply. I assign a firm to the group of firms with a pure strategy and a pure organizational architecture if (1) the firm's value for the exploration (or exploitation) measure is equal to or greater than the median of this measure; (2) the firm's value for the exploitation (or exploration) measure is below the median of this measure; and (3) the firm's value for the measure for exploratory (or exploitative) structures and HRM practices is equal to or greater than the median of this measure. In contrast, a firm is assigned to the group of firms with a pure strategy but without a pure organizational architecture if (1) and (2) apply but (3) does not.

I assign a firm to the group of firms with a no-emphasis strategy if the firm's values for both the exploration measure and the exploitation measure are below the medians of the respective measures. The group assignments in the technological ambidexterity sample are made analogously, as shown in Table 2.

${ }^{12}$ A dummy variable to account for data limitations is included in all regressions. If the measure for environmental dynamism is not available for a firm due to missing values, the environmental dynamism variable is coded 0, while the environmental dynamism missing dummy is coded 1 (Bloom and Van Reenen, 2007; Uotila et al., 2009). The environmental dynamism variable is missing for 27 observations in the individual ambidexterity sample (5.9 percent of observations) and for 47 observations in the technological ambidexterity sample ( 9.0 percent of the observations). 
I use additional dummy variables to account for industry effects. Particularly, I control for the firm's core industry membership at the one-digit SIC code level ${ }^{13}$ and for the firm's manufacturing sector membership at the two-digit SIC code level.

Finally, year dummies are included to control for time effects.

Descriptive statistics for both samples are provided in Table 3 and Table 4.

INSERT TABLE 4

INSERT TABLE 5

\section{RESULTS}

\section{Moderation effects models}

To mitigate the potential for multicollinearity when testing the moderation effects model 1 , I mean centered the linear terms of hybrid strategy and organizational ambidexterity before obtaining their product (Aiken and West, 1991; Jaccard and Turrisi, 2003). Multicollinearity concerns are further diminished because the variance inflation factors (VIFs) of all regressions for individual (technological) ambidexterity are never above 3.44 (4.34 and thus below the cut-off value of 10 (Cohen, Cohen, and West, 2002).

The ordinary least square (OLS) regression results for individual ambidexterity are reported in columns (1) and (2) of Table 5. The results in column (1) show that a hybrid strategy does not significantly affect performance if the hybrid strategy variable enters the regression in isolation. However, the interaction term of hybrid strategy and individual ambidexterity in column (2) is positive and significant. This supports hypothesis 1 that the effect of hybrid strategies on performance is positively moderated by organizational ambidexterity. Note that now also the over-

${ }^{13}$ As my survey focused on manufacturing firms, manufacturing (one-digit SIC codes 2 and 3 ) is the core industry for most observations in both samples (80.7 percent of the observations in the individual ambidexterity sample and 81.5 percent of the observations in the technological ambidexterity sample). 
all marginal effect of a hybrid strategy on firm performance is positive. The results for technological ambidexterity in columns (3) and (4) confirm this finding. ${ }^{14}$

INSERT TABLE 6

\section{Effects- and dummy-coding models}

Hypotheses 2 to 4 are tested with effects- and dummy-coding models 2,3 , 4, and 5 . The model and the reference group employed in every column are indicated at the top of Table $6 .{ }^{15}$

INSERT TABLE 7

Column (1) shows the results for effects-coding model 2. As shown, the average performance of the group of firms with a hybrid strategy and individual ambidexterity is significantly higher than the sample average performance, that is, the average of the average performances of all groups of firms $\left(2.9001^{* *}\right)$. Instead, the average performance of firms with a hybrid strategy but without individual ambidexterity is significantly lower than the sample average performance (-

\footnotetext{
14 Note that I employ two robustness tests for hypothesis 1 with alternative measures of hybrid strategy, individual ambidexterity, and technological ambidexterity. Obviously, if computing the hybrid strategy measure as the average of exploration and exploitation, a firm with an exploration score of 5 and an exploitation score of 1 and another firm with an exploration score of 3 and an exploitation score of 3 are assigned the same hybrid strategy score, namely 3. However, one could argue that the former firm is a pure explorer and only the latter firm pursues an actual hybrid strategy. The analogous reasoning applies to the individual ambidexterity and technological ambidexterity measures. First, to mitigate bias from this and ensure that only firms with an actual hybrid strategy, ambidextrous organizational architecture, and ambidextrous ICT are considered in the analysis, I recode the measures to 0 if at least one of their respective two components is below its median value. The results presented in Table 5 hold for both individual and technological ambidexterity (not reported). Second, using a dummy-coding model, as described above, I employ subgroup analysis as an alternative means to test hypothesis 1; that is, I compare the average performance of firms with a hybrid strategy and organizational ambidexterity with the average performance of firms with a hybrid strategy but without organizational ambidexterity. As outlined above, the group indicator variables for the dummy-coding models are created by the median-cutoff criterion, meaning that only firms with an actual hybrid strategy are coded as such a firm. The results support hypothesis 1 for individual and technological ambidexterity, are shown in Table 6, and described in more detail below.

${ }^{15}$ Note that dummy- and effects-coding are alternative methods but mathematically equivalent (Hardy, 1993; Spanos et al., 2004). As the same data are used in columns (1) to (5), they yield an identical $R^{2}$ and identical coefficients for all variables except for the group indicator variables. This also applies to columns (6) to (10).
} 
$1.8968^{* *}$ ). These results hold for technological ambidexterity, as shown in column (6). Thus, hypothesis 2 is supported for individual and technological ambidexterity. ${ }^{16}$

Column (3) shows dummy-coding model 3.The coefficient for the group of firms with a hybrid strategy and individual ambidexterity is positive and significant $\left(5.6936^{* * *}\right)$, indicating that these firms outperform firms with a no-emphasis strategy on average. In contrast, the coefficient for the group of firms with a hybrid strategy but without individual ambidexterity is insignificant, indicating that on average, there are no significant performance differences to the firms with a no-emphasis strategy (0.8967). These results hold for technological ambidexterity, as shown in column (8). Thus, hypothesis 3 is supported.

Columns (4) and (5) show models 4 and 5. As outlined above, the group of firms with a pure strategy is split into firms with or without pure structures and HRM practices. Column (4) uses firms with a pure strategy and pure structures and HRM practices as the reference group. As shown, firms with a hybrid strategy and individual ambidexterity do not display a significantly different average performance than the reference group (2.4523). However, firms with a hybrid strategy but without individual ambidexterity have a significantly lower average performance than firms with a pure strategy and pure structures and HRM practices $\left(-2.3447^{*}\right)$. These findings hold if firms with a pure strategy but without pure structures and HRM practices are used as the reference group in column (5). Thus, hypothesis 4 is supported for individual ambidexterity.

In columns (9) and (10), hypothesis 4a is fully supported for technological ambidexterity. In contrast, hypothesis $4 \mathrm{~b}$ is only supported in column (9). In column (10), the average performance differences between firms with a hybrid strategy and without technological ambidexterity as opposed to firms with a pure strategy and without pure ICT are insignificant. Given the

\footnotetext{
${ }^{16}$ Column (2) employs dummy-coding and uses firms with a hybrid strategy and without organizational ambidexterity as the reference group. Although not formally hypothesized, column (2) gives further support for hypothesis 1 on the moderating effect of organizational architecture in the hybrid strategyperformance relationship. In fact, the subgroup analysis employed in column (2) is an alternative to the moderation effects model 1 in Table 5 for testing the moderation approach (Venkatraman, 1989). According to column (2), firms with a hybrid strategy and individual ambidexterity have a significantly higher average performance than firms with a hybrid strategy but without individual ambidexterity $\left(4.7970^{* * *}\right)$. Thus, hypothesis 1 is again fully supported for individual ambidexterity. The finding holds for technological ambidexterity in column (7).
} 
abovementioned assumption that firms with a pure strategy but without pure ICT may, on average, underperform firms with a pure strategy and pure ICT, this finding is not surprising. However, hypothesis $4 \mathrm{~b}$ is only partly supported for technological ambidexterity.

\section{DISCUSSION AND CONCLUSIONS}

I examined the role of organizational architecture as a moderator of the hybrid strategyperformance relationship. Particularly, I focused on the roles of individual and technological ambidexterity in relatively small firms. Further, I examined the performance impact of hybrid strategies as compared to different reference groups. I employed a novel dataset from three independent sources and with objective performance data from annual firm accounts and found evidence that both individual and technological ambidexterity positively moderate the hybrid strategy-performance relationship. Further, I found hybrid strategies to outperform the entire sample and no-emphasis strategies in the presence of organizational ambidexterity, but to underperform the entire sample and match the performance of firms with no-emphasis strategies in the absence of organizational ambidexterity. Finally, I found hybrid strategies to match the performance of pure strategies in the presence of organizational ambidexterity but to underperform them in absence of organizational ambidexterity. These findings raise important issues for both theory and practice.

\section{Implications for research}

First and foremost, this study provides a conceptual advancement. To the best of my knowledge, this study is the first large-sample empirical analysis of the role of organizational architecture as a moderator of the hybrid strategy-performance relationship. Thus, this study is a first step to closing a gap between theoretical and empirical research on the performance impact of hybrid strategies. Particularly, the finding that the presence of an ambidextrous organizational architecture does not only change the strength but also the direction of a hybrid strategy's performance effect might offer an explanation for the fact that both positive and negative performance effects of hybrid strategies have been found in prior studies which disregarded organizational architecture. Second, to my knowledge, this study provides the first analysis of the potential of ICT to 
achieve organizational ambidexterity. Third, this study provides a methodological advancement by employing a variety of performance definitions. Fourth, this study is the first example to show that it can be fruitful to combine the largely disconnected theoretical and empirical research on classic typologies of corporate strategy as well as on ambidexterity. Finally, in addition to the theoretical and empirical advancements of this study, there is also a contribution with respect to the data-gathering methods used.

\section{Implications for managers}

With regard to managerial implications, this study draws a more differentiated picture of the performance effects of hybrid strategies than prior studies. First, for managers that pursue the exploratory as well as the exploitative success of their firms, this study confirms that hybrid strategies can indeed positively affect firm performance if suitable organizational arrangements are in place. Second, these organizational arrangements are less difficult to establish than prior studies have argued. Instead, a sophisticated combination of well-known and well-understood organizational structures and HRM practices is sufficient to provide organizational ambidexterity. Third, managers in relatively small firms should especially consider individual ambidexterity as the appropriate organizational solution for hybrid strategies. Fourth, managers should also draw their attention to the potential of ICT to achieve ambidexterity.

\section{Limitations and future research}

Of course, this study is not without limitations. Although the dataset is a major strength of this study and though several measures were undertaken to avoid any bias, I had to combine crosssectional data with time-series data. Future studies could employ actual time-series data on corporate strategy and organizational architecture. Further, to make firms within the study comparable and in order to focus on one questionnaire, my survey focused on manufacturing firms. To be able to conduct telephone interviews, my survey was limited to German and Polish firms. Finally, to fruitfully analyze the role of individual ambidexterity, I chose relatively small firms as subjects of the study. In sum, future studies could verify if the findings of this study are generalizable to other industries, other countries, and larger firms. Further, although the dataset al- 
lowed the assessment of objective performance data with a one-year lag, future studies should analyze the long-term performance impacts of hybrid strategies $(3,5$, or 10 years). Particularly, it would be interesting to see if hybrid strategies outperform pure strategies in the long term. Also, it would be interesting to compare the performance variation within the groups of firms with a hybrid strategy and with (or without) organizational ambidexterity to the performance variation within other groups of firms at a certain point in time (He and Wong, 2004) or over time (Levinthal and March, 1993). It would also be interesting to test if the moderating effect of organizational ambidexterity can be verified for structural, leadership-based, and informal ambidexterity. In addition, the potential of ICT to enhance organizational ambidexterity should be analyzed in more detail. Specifically, it would be interesting to examine whether ICT is particularly fruitful for enhancing specific types of organizational ambidexterity, or if it even enables new forms of organizational ambidexterity. In conclusion, I view this study as a promising step to understanding the role of organizational ambidexterity in the hybrid strategy-performance relationship. 


\section{References}

Adler PS, Borys B. 1996. Two Types of Bureaucracy: Enabling and Coercive. Administrative Science Quarterly 41(1): 61-89.

Adler PS, Goldoftas B, Levine D. 1999. Flexibility versus efficiency? A case study of model changeovers in the Toyota production system. Organization Science 10(1): 43-68.

Ai C, Norton EC. 2003. Interaction terms in logit and logit models. Economics Letters 80(1): 123-129.

Aiken LS, West SG. 1991. Multiple Regression: Testing and Interpreting Interactions. Sage: Newbury Park, CA, US.

Alavi M, Leidner DE. 2001. Review: Knowledge Management and Knowledge Management Systems: Conceptual Foundations and Research Issues. MIS Quarterly 25(1): 107-136.

Ambos TC, Mäkelä K, Birkinshaw J, D’Este P. 2008. When Does University Research Get Commercialized? Creating Ambidexterity in Research Institutions. Journal of Management Studies 45(8): 1424-1447.

Andersen JA, Jonsson P. 2006. Does organizational structure matter? On the relationship between the structure, functioning and effectiveness. International Journal of Innovation and Technology Management 3(3): 237-263.

Aral S, Weill P. 2007. IT Assets, Organizational Capabilities, and Firm Performance: How Resource Allocations and Organizational Differences Explain Performance Variation. Organization Science 18(5): 763-780.

Auh S, Mengue B. 2005. Balancing Exploration and Exploitation: The Moderating Role of Competitive Intensity. Journal of Business Research 58(12): 1652-1661.

Benner MJ, Tushman ML. 2003. Exploitation, Exploration, and Process Management: The Productivity Dilemma Revisited. Academy of Management Review 28(2): 238-256.

Birkinshaw JM. 2006. The ambidextrous organisation - driving leadership. Mannaz Leadership Newsletter June 2006. mannaz.com/Mail.asp?MailID=102\&TopicID=1160 [6 October 2009].

Birkinshaw JM, Gibson C. 2004a. Building Ambidexterity into the Organization. Sloan Management Review 45(4): 47-55.

Birkinshaw JM, Gibson C. 2004b. Building an Ambidextrous Organisation. Working Paper, Advanced Institute of Management Research, London, UK.

Birkinshaw JM, Gibson C. 2005. The Ambidextrous Organisation. Executive Briefing, Advanced Institute of Management Research, London, UK.

Bloom N, Garicano L, Sadun R, Van Reenen J. 2009. The Distinct Effects of Information Technology and Communication Technology on Firm Organization. Working Paper, Centre For Economic Performance, London School of Economics and Political Science, London, UK.

Bloom N, Sadun R, Van Reenen J. 2009a. Measuring and Explaining Decentralization Across Firms and Countries. Working Paper, Centre for Economic Performance, London School of Economics and Political Science, London, UK.

Bloom N, Kretschmer T, Van Reenen J (forthcoming). Determinants and Consequences of Family-Friendly Workplace Practices - An International Study. Strategic Management Journal.

Burns T, Stalker GM. 1961. The Management of Innovation. Tavistock: London, UK. 
Burton RM, Lauridsen J, Obel B. 2002. Return on Assets Loss from Situational and Contingency Misfits. Management Science 48(11): 1461-1485.

Campbell-Hunt C. 2000. What Have We Learned about Generic Competitive Strategy? A Meta-Analysis. Strategic Management Journal 21(2): 127-154.

Cao Q, Gedajlovic E, Zhang H. 2009. Unpacking Organizational Ambidexterity: Dimensions, Contingencies, and Synergistic Effects. Organization Science 20(4): 781-796.

Cardoso J, Bostrom RP, Sheth A. 2004. Workflow Management Systems and ERP Systems: Differences, Commonalities, and Applications. Information Technology and Management 5(3-4): 319-338.

Chari MDR, Devaraj S, David P. 2008. Research Note: The Impact of IT Investments and Diversification Strategies. Management Science 54(1): 224-234.

Cohen J, Cohen P, West SG. 2002. Applied Multiple Regression/Correlation Analysis for the Behavioral Sciences. Lawrence Erlbaum: Hillsdale, NJ, US.

Colombo MG, Delmastro M, Rabbiosi L. 2007. 'High performance' work practices, decentralization, and profitability: evidence from panel data. Industrial and Corporate Change 16(6): 1037-1067.

Conant JS, Mokwa MP, Varadarajan PR. 1990. Strategic Types, Distinctive Marketing Competencies and Organizational Performance: A Multiple Measures-Based Study. Strategic Management Journal 11(5): 365-383.

Curry A, Stancich L. 2000. The intranet - an intrinsic component of strategic information management? International Journal of Information Management 20(4): 249-268.

Daft RL, Sormunen J, Parks D. 1988. Chief Executive Scanning, Environmental Characteristics, and Company Performance: An Empirical Study. Strategic Management Journal 9(2): 123-139.

Delery JE, Doty DH. 1996. Modes of Theorizing in Strategic Human Resource Management: Tests of Universalistic, Contingency, and Configurational Performance Predictions. Academy of Management Journal 39(4): 802-835.

Dess GG, Davis PS. 1984. Porter's (1980) Generic Strategies as Determinants of Strategic Group Membership and Organizational Performance. Academy of Management Journal 27(3): 467-488.

Dewett T, Jones GR. 2001. The role of information technology in the organization: a review, model, and assessment. Journal of Management 27(3): 313-346.

Diamantopoulos A, Riefler P, Roth KP. 2008. Advancing formative measurement models. Journal of Business Research 61(12): 1203-1218.

Doty DH, Glick WH, Huber GP. 1993. Fit, Equifinality, and Organizational Effectiveness: A Test of Two Configurational Theories. Academy of Management Journal 36(6): 11961250.

Duncan RB. 1976. The ambidextrous organization: Designing dual structures for innovation. In The Management of Organization Design, Kilmann RH, Pondy LR, Slevin DP (eds.). Elsevier: New York, US.

Ellis CA, Gibbs SJ, Rein GL. 1991. Groupware: Some issues and experiences. Communications of the ACM 34(1): 38-58.

George JF, King JL. 1991. Examining the computing and centralization debate. Communications of the ACM 34(7): 62-72.

Ghemawat PJ, Ricart I Costa JE. 1993. The organizational tension between static and dynamic efficiency. Strategic Management Journal 14(Winter Special Issue): 59-73. 
Gibson C, Birkinshaw J. 2004. The antecedents, consequences, and mediating role of organizational ambidexterity. Academy of Management Journal 47(2): 209-226.

Ginsburg M, Duliba K. 1997. Enterprise-Level Groupware Choices: Evaluating Lotus Notes and Intranet-Based Solutions. Journal of Collaborative Computing 6(2-3): 201225.

Grant RA, Higgins C. 1991. The Impact of Computerized Performance Monitoring on Service Work: Testing a Causal Model. Information Systems Research 2(2): 116-142.

Grudin J. 1994. Groupware and social dynamics: eight challenges for developers. Communications of the ACM 37(1): 92-105.

Gulati R, Puranam P. 2009. Renewal Through Reorganization: The Value of Inconsistencies Between Formal and Informal Organization. Organization Science 20(2): 422440.

Gulati R, Puranam P, Tushman M. 2009. Strategy and the Design of Organizational Architecture, Call for Papers for a Special Issue of the Strategic Management Journal, Strategic Management Society, Chicago, IL, US.

Gupta AK, Smith KG, Shalley CE. 2006. The interplay between exploration and exploitation. Academy of Management Journal 49(4): 693-706.

Hall WK. 1980. Survival strategies in a hostile environment. Harvard Business Review 58(5): 75-85.

Hambrick DC. 1983a. Some Tests of the Effectiveness and Functional Attributes of Miles and Snow's Strategic Types. Academy of Management Journal 26(1): 5-26.

Hambrick DC. 1983b. High Profit Strategies in Mature Capital Goods Industries: A Contingency Approach. Academy of Management Journal 26(4): 687-707.

Hanks SH, Watson CJ, Jansen E, Chandler GN. 1993. Tightening the Life-Cycle Construct: A Taxonomic Study of Growth Stage Configurations in High-Technology Organizations. Entrepreneurship: Theory and Practice 18(2): 5-29.

Hardy M. 1993. Regression with Dummy Variables. Sage: Thousand Oaks, CA, US.

He Z-L, Wong P-K. 2004. Exploration vs. exploitation: An empirical test of the ambidexterity hypothesis. Organization Science 15(4): 481-531.

Hendricks KB, Singhal VR, Stratman JK. 2007. The impact of enterprise systems on corporate performance: A study of ERP, SCM, and CRM system implementations. Journal of Operations Management 25(1): 65-82.

Hitt LM, Wu DJ, Zhou X. 2002. Investment in Enterprise Resource Planning: Business Impact and Productivity Measures. Journal of Management Information Systems 19(1): 71-98.

Hoetker G. 2007. The use of logit and probit models in strategic management research: critical issues. Strategic Management Journal 28(4): 331-343.

Holmqvist M. 2004. Experiential Learning Processes of Exploitation and Exploration Within and Between Organizations: An Empirical Study of Product Development. Organization Science 15(1): 70-81.

Huber GP. 1990. A Theory of the Effects of Advanced Information Technologies on Organizational Design, Intelligence, and Decision Making. Academy of Management Review 15(1): 47-71.

Jaccard JJ, Turrisi R. 2003. Interaction Effects in Multiple Regression. Sage: Thousand Oaks, CA, US. 
Jackson SE, Schuler RS, Rivero JC. 1989. Organizational characteristics as predictors of personnel practices. Personnel Psychology 42(4): 727-786.

Jansen JJP. 2005. Ambidextrous Organizations: A Multiple-level Study of Absorptive Capacity, Exploratory and Exploitative Innovation, and Performance. Unpublished Dissertation, ERIM, Rotterdam School of Management, Erasmus University, Rotterdam, Netherlands. Available at: ep.eur.nl/handle/1765/6774 [7 October 2009].

Jansen JJP, Tempelaar MP, Van den Bosch FAJ, Volberda HW. 2009. Structural Differentiation and Ambidexterity: The Mediating Role of Integration Mechanisms. Organization Science 20(4): 797-811.

Jansen JJP, Van den Bosch FAJ, Volberda HW. 2005a. Exploratory innovation, exploitative innovation, and ambidexterity: The impact of environmental and organizational antecedents. Schmalenbach Business Review 57(4): 351-363.

Jansen JJP, Van den Bosch FAJ, Volberda HW. 2005b. Managing potential and realized absorptive capacity: How do organizational antecedents matter? Academy of Management Journal 48(6): 999-1015.

Jansen JJP, Van den Bosch FAJ, Volberda HW. 2006. Exploratory Innovation, Exploitative Innovation, and Performance: Effects of Organizational Antecedents and Environmental Moderators. Management Science 52(11): 1661-1674.

Jarvis CB, MacKenzie SB, Podsakoff PM. 2003. A Critical Review of Construct Indicators and Measurement Model Misspecification in Marketing and Consumer Research. Journal of Consumer Research 30(2): 199-218.

Kane GC, Alavi M. 2007. Information Technology and Organizational Learning: An Investigation of Exploration and Exploitation Process. Organization Science 18(5): 796812.

Kotha S, Vadlamani BL. 1995. Assessing generic strategies: an empirical investigation of two competing typologies in discrete manufacturing industries. Strategic Management Journal 16(1): 75-83.

Kyriakopoulos K, Moorman C. 2004. Tradeoffs in marketing exploitation and exploration strategies: The overlooked role of market orientation. International Journal of Research in Marketing 21(3): 219-240.

Lee CC, Grover V. 2000. Exploring Mediation Between Environmental and Structural Attributes: The Penetration of Communication Technologies in Manufacturing Organizations. Journal of Management Information Systems 16(3): 187-217.

Levinthal DA, March JG. 1993. The Myopia of Learning. Strategic Management Journal, 14(Winter Special Issue): 95-112.

Lubatkin MH, Simsek Z, Ling Y, Veiga JF. 2006. Ambidexterity and Performance in Smallto Medium-Sized Firms: The Pivotal Role of Top Management Team Behavioral Integration. Journal of Management 32(5): 646-672.

March JG. 1991. Exploration and exploitation in organizational learning. Organization Science 2(1): 71-87.

May RC, Stewart WH, Sweo R. 2000. Environmental scanning behavior in a transitional economy: Evidence from Russia. Academy of Management Journal 43(3): 403-427.

Miles RE, Snow CC. 1978. Organizational strategy, structure, and process. McGraw-Hill: New York, US.

Miller A, Dess GG. 1993. Assessing Porter's (1980) model in terms of its generalizability, accuracy and simplicity. Journal of Management Studies 30(4): 553-585. 
Miller D. 1992. The Generic Strategy Trap. Journal of Business Strategy 13(1): 37-41.

Miller D, Friesen PH. 1985. A Longitudinal Study of the Corporate Life Cycle. Management Science 30(10): 1161-1183.

Miller D, Friesen PH. 1986. Porter's (1980) Generic Strategies and Performance: An Empirical Examination with American Data: Part II: Performance Implications. Organization Studies 7(3): 255-261.

Miller D, Toulouse JM. 1998. Quasi-rational Organizational Responses: Functional and Cognitive Sources of Strategic Simplicity. Canadian Journal of Administrative Sciences 15(3): 230-244.

Mintzberg H. 1978. Patterns in Strategy Formation. Management Science 24(9): 934948.

Mom TJM, Van Den Bosch FAJ, Volderba HW. 2003. Managing concurrently the process of knowledge exploration and exploitation: the influence of knowledge exchange determinants and the introduction of an intranet. Working Paper, Department of Strategic Management and Business Environment, Rotterdam School of Management, Erasmus University, Rotterdam, Netherlands.

Mom TJM, Van Den Bosch FAJ, Volderba HW. 2009. Understanding Variation in Managers' Ambidexterity: Investigating Direct and Interaction Effects of Formal Structural and Personal Coordination Mechanisms. Organization Science 20(4): 812-828.

Moore M. 2005. Towards a Confirmatory Model of Retail Strategy Types: An Empirical Test of Miles and Snow. Journal of Business Research 58(5): 696-704.

Nahm AY, Vonderembse MA, Koufteros XA. 2003. The impact of organizational structure on time-based manufacturing and plant performance. Journal of Operations Management 21(3): 281-306.

Norton EC, Wang H, Ai C. 2004. Computing interaction effects and standard errors in logit and probit models. The Stata Journal 4(2): 154-167.

Nunally J. 1978. Psychometric theory. McGraw-Hill: New York, US.

Oh W, Pinsonneault A. 2007. On the Assessment of the Strategic Value of Information Technologies: Conceptual and Analytical Approaches. MIS Quarterly 21(2): 239-265.

O'Reilly C, Tushman ML. 2008. Ambidexterity as a Dynamic Capability: Resolving the Innovator's Dilemma. In Research in Organizational Behavior, Staw BM (ed.). JAI Press: Greenwich, CT, US.

Orlikowski WJ, Robey D. 1991. Information Technology and the Structuring of Organizations. Information Systems Research 2(2): 143-169.

Parnell JA. 1997. New Evidence in the Generic Strategy and Business Performance Debate: A Research Note. British Journal of Management 8(2): 175-81.

Parnell JA, Hershey L. 2005. The Strategy-performance relationship revisited: The blessing and curse of the combination strategy. International Journal of Commerce and Management 15(1): 17-33.

Parnell JA, Lester DL, Menefee ML. 2000. Strategy as a response to organizational uncertainty: an alternative perspective on the strategy-performance relationship. Management Decision 38(8): 520-530.

Parnell JA, Wright P. 1993. Generic Strategy and Performance: an Empirical Test of the Miles and Snow Typology. British Journal of Management 4(1): 29-36. 
Pinsonneault A, Kraemer KL. 1997. Middle Management Downsizing: An Empirical Investigation of the Impact of Information Technology. Management Science 43(5): 659679.

Podsakoff PM, MacKenzie SB, Podsakoff NP. 2003. Common Method Biases in Behavioral Research: A Critical Review of the Literature and Recommended Remedies. Journal of Applied Psychology 88(5): 879-903.

Porter ME. 1980. Competitive Strategy. Free Press: New York, US.

Porter ME. 1985. Competitive Advantage. Free Press: New York, US.

Porter ME. 1996. What is a strategy? Harvard Business Review 74(6): 61-78.

Pugh DS. 1973. The Measurement of Organizational structures. Does context determine form? Organizational Dynamics 1(4): 19-34.

Radner R. 1993. The Organization of Decentralized Information Processing. Econometrica 61(5): 1109-1146.

Raisch S, Birkinshaw J. 2008. Organizational Ambidexterity: Antecedents, Outcomes, and Moderators. Journal of Management 34(3): 375-409.

Raisch S, Birkinshaw J, Probst G, Tushman ML. 2009. Organizational Ambidexterity: Balancing Exploitation and Exploration for Sustained Performance. Organization Science 20(4): 685-695.

Raisch S, Hotz F. 2010. Shaping the context for learning: Corporate alignment initiatives, environmental munificence, and firm performance. In Strategic reconfigurations: Building dynamic capabilities in rapid-innovation-based industries, Wall S, Zimmermann C, Klingebiel R, Lange D (eds.). Edward Elgar: Cheltenham, UK.

Roberts J. 2007. The modern firm: Organizational design for performance and growth. Oxford University Press: New York, US.

Rothaermel FT, Alexandre MT. 2009. Ambidexterity in Technology Sourcing: The Moderating Role of Absorptive Capacity. Organization Science 20(4): 759-780.

Schuler RS, Jackson SE. 1987. Linking Competitive Strategies with Human Resource Management Practices. Academy of Management Executive 1(3): 207-219.

Sheremata WA. 2000. Centrifugal and Centripetal Forces in Radical New Product Development under Time Pressure. Academy of Management Review 25(2): 389-408.

Simsek Z. 2009. Organizational Ambidexterity: Towards a Multilevel Understanding. Journal of Management Studies 46(4): 597-624.

Smith WK, Tushman ML. 2005. Managing Strategic Contradictions: A Top Management Model for Managing Innovation Streams. Organization Science 16(5): 522-536.

Spanos YE, Zaralis G, Lioukas S. 2004. Strategy and industry effects on profitability: evidence from Greece. Strategic Management Journal 25(2): 139-165.

Stohr EA, Zhao JL. 2001. Workflow Automation: Overview and Research Issues. Information Systems Frontiers 3(3): 281-296.

Thornhill S, White RE. 2007. Strategic purity: A multi-industry evaluation of pure vs. hybrid business strategies. Strategic Management Journal 28(5): 553-561.

Tushman ML, O’Reilly C. 1996. Ambidextrous organizations: Managing evolutionary and revolutionary change. California Management Review 38(4): 8-30.

Uotila J, Maula M, Keil T, Zahra SA. 2009. Exploration, exploitation, and financial performance: analysis of S\&P 500 corporations. Strategic Management Journal 30(2): 221231. 
Van Looy B, Martens T, Debackere K. 2005. Organizing for Continuous Innovation: On the Sustainability of Ambidextrous Organizations. Creativity and Innovation Management 14(3): 208-221.

Venkatraman N. 1989. The Concept of Fit in Strategy Research: Toward Verbal and Statistical Correspondence. Academy of Management Review 14(3): 423-444.

Venkatraman N, Lee C-H, Iyer B. 2007. Strategic Ambidexterity and Sales Growth: A Longitudinal Test in the Software Sector. Working Paper, Boston University School of Management, Boston, MA, US.

White RE. 1986. Generic Business Strategies, Organizational Context and Performance: An Empirical Investigation. Strategic Management Journal 7(3): 217-231.

Youndt MA, Snell SA, Dean JW, Lepak D. 1996. Human Resource Management, Manufacturing Strategy, and Firm Performance. Academy of Management Journal 39(4): 836866. 

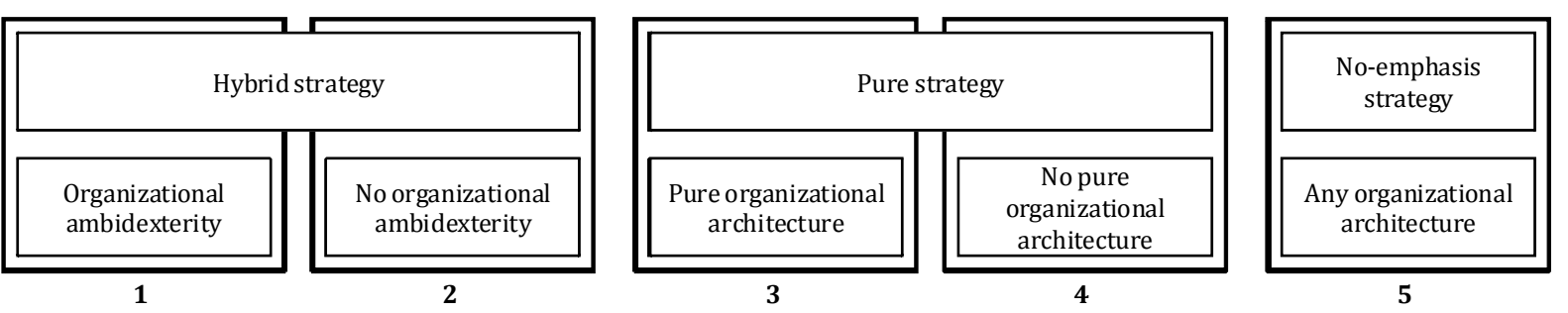

Figure 1. Five groups of firms split by corporate strategy and organizational architecture

Table 1. Summary of empirical studies

\begin{tabular}{ll}
\hline Findings on hybrid strategies & Studies \\
\hline
\end{tabular}

\section{Studies on Porter's strategy typology}

only pure strategies are related to above-average firm performance Dess and Davis, 1984; Hall, 1980

pure strategies outperform hybrid strategies, and that hybrid strategies only perform as well as no-emphasis strategies

Miller and Friesen, 1986

pure strategies do not always outperform hybrid strategies

Milles and Dess, 1993

hybrid strategies can also lead to above-average firm performance or even outperform no-emphasis strategies

Miller, 1992; Spanos et al., 2004;

White, 1986

hybrid strategies outperform one or both types of pure strategies

Spanos et al., 2004; White, 1986

\section{Studies on Miles and Snow's strategy typology}

positive performance effect for prospector, defender, and analyzer strategies but a negative effect for no-emphasis strategies

Moore, 2005

prospectors, defenders, and analyzers perform equally well and outperform no-emphasis strategies

Conant, Mokwa, and Varadarajan, 1990

analyzers can outperform prospectors and defenders in certain contexts

Hambrick, 1983a; Parnell and Wright, 1993

\section{Studies on Miles and Snow's strategy typology}

hybrid strategies have a positive impact on firm performance

Cao et al., 2009; Gibson and Birkinshaw, 2004; He and Wong, 2004;

hybrid strategies do not significantly affect firm performance

Kyriakopoulos and Moorman, 2004;

Venkatraman, Lee, and Iyer, 2007

\section{Studies on similar strategy typologies, derived from the three typologies above}

the firms in high profit clusters pursue pure strategies

that the degree of strategic purity positively impacts firm performance

hybrid strategies positively correlate with firm performance in some cases

hybrid strategies lead to above-average firm performance in general, or may even outperform no-emphasis and pure strategies
Hambrick, 1983b

Thornhill and White, 2007

Parnell and Hershey, 2005

Parnell, 1997; Parnell, Lester, and Menefee, 2000 
Table 2. ICT types

\begin{tabular}{|c|c|}
\hline ploratory ICT & \\
\hline Groupware applications & $\begin{array}{l}\text { Collaboration software (e-mail, shared calendars, } \\
\text { shared document storage and management, etc.) } \\
\text { Office automation software } \\
\text { Other groupware software }\end{array}$ \\
\hline Corporate intranets & $\begin{array}{l}\text { Frame-relay } \\
\text { Leased-line } \\
\text { Wide-area network }\end{array}$ \\
\hline Exploitative ICT & \\
\hline ERP applications & $\begin{array}{l}\text { Accounting software } \\
\text { Human resource management software } \\
\text { Supply chain management software } \\
\text { Customer relationship management software } \\
\text { Other ERP software }\end{array}$ \\
\hline Workflow applications & $\begin{array}{l}\text { Application server software } \\
\text { Content management software } \\
\text { Document management software } \\
\text { Enterprise application integration software } \\
\text { Portal management software }\end{array}$ \\
\hline
\end{tabular}

Table 3. Groups in the individual and technological ambidexterity samples

\begin{tabular}{lcc|lcc}
\hline Groups in ind. ambid. sample & Firms & Obs. & Groups in techn. ambid. sample & Firms & Obs. \\
\hline $\begin{array}{l}\text { Hybrid strategy } \\
\text { and individual ambidexterity }\end{array}$ & 27 & 45 & $\begin{array}{l}\text { Hybrid strategy } \\
\text { and technological ambid. }\end{array}$ & 53 & 90 \\
$\begin{array}{l}\text { Hybrid strategy } \\
\text { w/o individual ambidexterity }\end{array}$ & 64 & 109 & $\begin{array}{l}\text { Hybrid strategy } \\
\text { w/o technological ambid. }\end{array}$ & 57 & 87 \\
$\begin{array}{l}\text { Pure strategy } \\
\text { and pure structures/HRM }\end{array}$ & 62 & 113 & $\begin{array}{l}\text { Pure strategy } \\
\text { and pure ICT }\end{array}$ \\
$\begin{array}{l}\text { Pure strategy } \\
\text { w/o pure structures/HRM }\end{array}$ & 49 & 86 & $\begin{array}{l}\text { Pure strategy } \\
\text { w/o pure ICT }\end{array}$ & 91 & 166 \\
No-emphasis strategy & 56 & 104 & No-emphasis strategy & 37 & 55 \\
Total & 258 & 457 & Total & 68 & 122 \\
\hline
\end{tabular}

Note that a total of 306 firms for the technological ambidexterity sample ( $>302$ as stated in regressions) results from firms that have changed groups over time through changes in their ICT adoption 
Table 4. Descriptive statistics for the individual ambidexterity sample

\begin{tabular}{lccccccc}
\hline Variable & Firms & Obs. & Median & Mean & Std. dev & Min & Max \\
\hline ROA (t) & 258 & 457 & 8.9585 & 10.0292 & 14.2045 & -33.3887 & 136.0431 \\
ROA & 258 & 457 & 7.9589 & 9.4653 & 13.3181 & -33.7865 & 87.8834 \\
Firm size (ln) & 258 & 457 & 5.5134 & 5.5852 & 0.9428 & 1.3863 & 8.2721 \\
Firm age (ln) & 258 & 457 & 3.2958 & 3.2403 & 0.9473 & 0 & 5.2149 \\
Environmental dyn. & 258 & 457 & 23.5000 & 22.4032 & 7.3501 & 0 & 39.6250 \\
Hybrid strategy (mc) & 258 & 457 & -0.0209 & 0 & 0.5170 & -1.8334 & 1.2708 \\
Ind. ambid. (mc) & 258 & 457 & 0.0532 & 0 & 0.4527 & -1.6933 & 1.1426 \\
$\begin{array}{l}\text { Hybrid strategy (mc) } \\
\text { × ind. ambid. (mc) }\end{array}$ & 258 & 457 & 0.0106 & 0.0367 & 0.2514 & -0.6263 & 1.5418 \\
Firm size (ut) & 258 & 457 & 248 & 423.1745 & 504.0048 & 4 & 3,913 \\
Firm age (ut) & 258 & 457 & 26 & 37.1422 & 35.4999 & 0 & 183 \\
\hline
\end{tabular}

(ln) natural logarithm; (mc) mean centered; (ut) untransformed, not used in multivariate analysis; all variables are at time $\mathrm{t}-1$ if not otherwise stated.

Table 5. Descriptive statistics for the technological ambidexterity sample

\begin{tabular}{lccccccc}
\hline Variable & Firms & Obs. & Median & Mean & Std. dev. & Min & Max \\
\hline ROA (t) & 302 & 520 & 7.7171 & 8.6523 & 12.7380 & -36.8692 & 79.9198 \\
ROA & 302 & 520 & 7.3865 & 8.2637 & 13.3725 & -55.8324 & 87.8834 \\
Firm size (ln) & 302 & 520 & 5.5134 & 5.5492 & 0.9304 & 1.3863 & 8.2721 \\
Firm age (ln) & 302 & 520 & 3.2958 & 3.2064 & 0.9410 & 0 & 5.2149 \\
Environmental dyn. & 302 & 520 & 23 & 21.4178 & 8.2368 & 0 & 39.6250 \\
Hybrid strategy (mc) & 302 & 520 & 0.0201 & 0 & 0.5234 & -1.8201 & 1.2840 \\
Techn. ambid. (mc) & 302 & 520 & 0.1409 & 0 & 0.1735 & -0.6091 & 0.3909 \\
Hybrid strategy (mc) & 302 & 520 & .0064 & -.0032 & .0887 & -.4586 & .3981 \\
$\times$ techn. ambid. (mc) & & & & & & & \\
Firm size (ut) & 302 & 520 & 248 & 405.7591 & 497.0403 & 4 & 3,913 \\
Firm age (ut) & 302 & 520 & 26 & 36.0231 & 35.2535 & 0 & 183 \\
\hline
\end{tabular}

(ln) natural logarithm; (mc) mean centered; (ut) untransformed, not used in multivariate analysis; all variables are at time $\mathrm{t}-1$ if not otherwise stated. 
Table 6. Test of hypothesis 1

\begin{tabular}{|c|c|c|c|c|}
\hline \multirow{3}{*}{$\begin{array}{l}\text { Dependent variable } \\
\text { Sample }\end{array}$} & \multicolumn{4}{|c|}{$\mathrm{ROA}(\mathrm{t})$} \\
\hline & \multicolumn{2}{|c|}{ Individual ambidexterity } & \multicolumn{2}{|c|}{ Technological ambidexterity } \\
\hline & $(1)$ & $(2)$ & $(3)$ & $(4)$ \\
\hline Firm size $(\ln )$ & $\begin{array}{l}-0.1047 \\
(0.4271)\end{array}$ & $\begin{array}{l}-0.2742 \\
(0.4293)\end{array}$ & $\begin{array}{c}0.0045 \\
(0.3963)\end{array}$ & $\begin{array}{c}0.0713 \\
(0.4108)\end{array}$ \\
\hline Firm age $(\ln )$ & $\begin{array}{c}0.2832 \\
(0.4111)\end{array}$ & $\begin{array}{c}0.1965 \\
(0.3980)\end{array}$ & $\begin{array}{c}0.5854 \\
(0.3921)\end{array}$ & $\begin{array}{c}0.5641 \\
(0.3993)\end{array}$ \\
\hline $\mathrm{ROA}(\mathrm{t}-1)$ & $\begin{array}{c}0.8051^{* * *} \\
(0.0764)\end{array}$ & $\begin{array}{c}0.8019 * * * \\
(0.0768)\end{array}$ & $\begin{array}{c}0.6222^{* * *} \\
(0.0762)\end{array}$ & $\begin{array}{c}0.6198^{* * *} \\
(0.0767)\end{array}$ \\
\hline $\begin{array}{l}\text { Environmental } \\
\text { dynamism }\end{array}$ & $\begin{array}{c}0.0277 \\
(0.0887)\end{array}$ & $\begin{array}{c}0.0408 \\
(0.0900)\end{array}$ & $\begin{array}{c}0.0010 \\
(0.0966)\end{array}$ & $\begin{array}{c}0.0141 \\
(0.0981)\end{array}$ \\
\hline $\begin{array}{l}\text { Hybrid } \\
\text { strategy }\end{array}$ & $\begin{array}{c}1.1801 \\
(0.8829)\end{array}$ & $\begin{array}{c}1.2929 \\
(0.8919)\end{array}$ & $\begin{array}{c}0.7321 \\
(0.8988)\end{array}$ & $\begin{array}{c}0.7011 \\
(0.8756)\end{array}$ \\
\hline $\begin{array}{l}\text { Individual } \\
\text { ambidexterity }\end{array}$ & & $\begin{array}{c}1.2142 \\
(0.9168)\end{array}$ & & \\
\hline $\begin{array}{l}\text { Hybrid strategy } \\
\times \text { individual ambid. }\end{array}$ & & $\begin{array}{l}2.8382 * * \\
(1.3339)\end{array}$ & & \\
\hline $\begin{array}{l}\text { Technological } \\
\text { ambidexterity }\end{array}$ & & & & $\begin{array}{l}-0.1827 \\
(2.6043)\end{array}$ \\
\hline $\begin{array}{l}\text { Hybrid strategy } \\
\times \text { technological ambid. }\end{array}$ & & & & $\begin{array}{c}12.6541 * * * \\
(4.6075)\end{array}$ \\
\hline $\begin{array}{l}\text { Further } \\
\text { controls }\end{array}$ & Indust & $\begin{array}{l}\text { acturing sec } \\
\text { ironmental }\end{array}$ & $\begin{array}{l}\text { ear dummie } \\
n \text { missing d }\end{array}$ & y dummy; \\
\hline Firms & 258 & 258 & 302 & 302 \\
\hline Observations & 457 & 457 & 520 & 520 \\
\hline $\mathrm{R}^{2}$ & 0.61 & 0.62 & 0.50 & 0.50 \\
\hline
\end{tabular}

${ }^{*} \mathrm{p}<0.1 ;{ }^{* *} \mathrm{p}<0.05$; ${ }^{* * *} \mathrm{p}<0.01$; time period 2005-2008; OLS regressions used in all columns; standard errors in parentheses clustered by firm and Huber-White robust to heteroskedasticity and autocorrelation of unknown form 
Table 7. Test of hypotheses 1 to 4

\begin{tabular}{|c|c|c|c|c|c|c|c|c|c|c|}
\hline \multirow{3}{*}{$\begin{array}{l}\text { Dependent variable } \\
\text { Sample } \\
\text { Coding }\end{array}$} & \multicolumn{10}{|c|}{$\mathrm{ROA}(\mathrm{t})$} \\
\hline & \multicolumn{5}{|c|}{ Individual ambidexterity } & \multicolumn{5}{|c|}{ Technological ambidexterity } \\
\hline & Effects & Dummy & Dummy & Dummy & Dummy & Effects & Dummy & Dummy & Dummy & Dummy \\
\hline Reference group & $\begin{array}{c}\text { Entire } \\
\text { sample }\end{array}$ & $\begin{array}{l}\text { Hybrid strat. } \\
\text { w/o i. ambid. }\end{array}$ & $\begin{array}{c}\text { No-emphasis } \\
\text { strategy }\end{array}$ & $\begin{array}{l}\text { Pure strategy } \\
\text { and pure str. }\end{array}$ & $\begin{array}{l}\text { Pure strategy } \\
\text { w/o pure str. }\end{array}$ & $\begin{array}{c}\text { Entire } \\
\text { sample }\end{array}$ & $\begin{array}{l}\text { Hybrid strat. } \\
\text { w/o t. ambid. }\end{array}$ & $\begin{array}{c}\text { No-emphasis } \\
\text { strategy }\end{array}$ & $\begin{array}{l}\text { Pure strategy } \\
\text { and pure ICT }\end{array}$ & $\begin{array}{l}\text { Pure strategy } \\
\text { w/o pure ICT }\end{array}$ \\
\hline & $(1)$ & $(2)$ & (3) & $(4)$ & (5) & $(6)$ & (7) & $(8)$ & (9) & $(10)$ \\
\hline Firm size (ln) & $\begin{array}{l}-0.4343 \\
(0.4114)\end{array}$ & $\begin{array}{l}-0.4343 \\
(0.4114)\end{array}$ & $\begin{array}{l}-0.4343 \\
(0.4114)\end{array}$ & $\begin{array}{l}-0.4343 \\
(0.4114)\end{array}$ & $\begin{array}{l}-0.4343 \\
(0.4114)\end{array}$ & $\begin{array}{l}-0.2745 \\
(0.4146)\end{array}$ & $\begin{array}{l}-0.2745 \\
(0.4146)\end{array}$ & $\begin{array}{l}-0.2745 \\
(0.4146)\end{array}$ & $\begin{array}{l}-0.2745 \\
(0.4146)\end{array}$ & $\begin{array}{l}-0.2745 \\
(0.4146)\end{array}$ \\
\hline Firm age (ln) & $\begin{array}{c}0.3067 \\
(0.3793)\end{array}$ & $\begin{array}{c}0.3067 \\
(0.3793)\end{array}$ & $\begin{array}{c}0.3067 \\
(0.3793)\end{array}$ & $\begin{array}{c}0.3067 \\
(0.3793)\end{array}$ & $\begin{array}{c}0.3067 \\
(0.3793)\end{array}$ & $\begin{array}{c}0.5482 \\
(0.3935)\end{array}$ & $\begin{array}{c}0.5482 \\
(0.3935)\end{array}$ & $\begin{array}{c}0.5482 \\
(0.3935)\end{array}$ & $\begin{array}{c}0.5482 \\
(0.3935)\end{array}$ & $\begin{array}{c}0.5482 \\
(0.3935)\end{array}$ \\
\hline $\mathrm{ROA}(\mathrm{t}-1)$ & $\begin{array}{c}0.7966^{* * *} \\
(0.0791)\end{array}$ & $\begin{array}{c}0.7966^{* * *} \\
(0.0791)\end{array}$ & $\begin{array}{c}0.7966^{* * *} \\
(0.0791)\end{array}$ & $\begin{array}{c}0.7966^{* * *} \\
(0.0791)\end{array}$ & $\begin{array}{c}0.7966^{* * *} \\
(0.0791)\end{array}$ & $\begin{array}{c}0.6112^{* * *} \\
(0.0759)\end{array}$ & $\begin{array}{c}0.6112^{* * *} \\
(0.0759)\end{array}$ & $\begin{array}{c}0.6112^{* * *} \\
(0.0759)\end{array}$ & $\begin{array}{c}0.6112^{* * *} \\
(0.0759)\end{array}$ & $\begin{array}{c}0.6112^{* * *} \\
(0.0759)\end{array}$ \\
\hline $\begin{array}{l}\text { Environmental } \\
\text { dynamism }\end{array}$ & $\begin{array}{c}0.0588 \\
(0.0818)\end{array}$ & $\begin{array}{c}0.0588 \\
(0.0818)\end{array}$ & $\begin{array}{c}0.0588 \\
(0.0818)\end{array}$ & $\begin{array}{c}0.0588 \\
(0.0818)\end{array}$ & $\begin{array}{c}0.0588 \\
(0.0818)\end{array}$ & $\begin{array}{l}-0.0101 \\
(0.0912)\end{array}$ & $\begin{array}{c}-0.0101 \\
(0.0912)\end{array}$ & $\begin{array}{l}-0.0101 \\
(0.0912)\end{array}$ & $\begin{array}{l}-0.0101 \\
(0.0912)\end{array}$ & $\begin{array}{l}-0.0101 \\
(0.0912)\end{array}$ \\
\hline $\begin{array}{l}\text { Hybrid strategy } \\
\text { and ind./techn. ambidexterity }\end{array}$ & $\begin{array}{l}2.9001^{* *} \\
(1.1450)\end{array}$ & $\begin{array}{l}4.7970 * * * \\
(1.6420)\end{array}$ & $\begin{array}{c}5.6936 * * * \\
(1.5888)\end{array}$ & $\begin{array}{c}2.4523 \\
(1.6280)\end{array}$ & $\begin{array}{c}1.5578 \\
(1.6173)\end{array}$ & $\begin{array}{c}2.0802 * \\
(1.0617)\end{array}$ & $\begin{array}{l}4.0780 * * * \\
(1.5141)\end{array}$ & $\begin{array}{l}4.3652^{* * *} \\
(1.5145)\end{array}$ & $\begin{array}{l}-0.0028 \\
(1.3311)\end{array}$ & $\begin{array}{c}1.9604 \\
(1.8032)\end{array}$ \\
\hline $\begin{array}{l}\text { Hybrid strategy } \\
\text { w/o ind./techn. ambidexterity }\end{array}$ & $\begin{array}{c}-1.8968^{* *} \\
(0.8615)\end{array}$ & & $\begin{array}{c}0.8967 \\
(1.1159)\end{array}$ & $\begin{array}{l}-2.3447^{*} \\
(1.3519)\end{array}$ & $\begin{array}{l}-3.2392 * * \\
(1.3687)\end{array}$ & $\begin{array}{c}-1.9979 * * \\
(0.8548)\end{array}$ & & $\begin{array}{c}0.2872 \\
(1.2342)\end{array}$ & $\begin{array}{c}-4.0809 * * * \\
(1.1855)\end{array}$ & $\begin{array}{l}-2.1176 \\
(1.5511)\end{array}$ \\
\hline $\begin{array}{l}\text { Pure strategy } \\
\text { and pure structures/HRM/ICT }\end{array}$ & $\begin{array}{c}0.4478 \\
(0.8287)\end{array}$ & $\begin{array}{l}2.3447^{*} \\
(1.3519)\end{array}$ & $\begin{array}{l}3.2413^{* * *} \\
(1.1556)\end{array}$ & & $\begin{array}{l}-0.8946 \\
(1.2456)\end{array}$ & $\begin{array}{l}2.0830 * * * \\
(0.6649)\end{array}$ & $\begin{array}{l}4.0809 * * * \\
(1.1855)\end{array}$ & $\begin{array}{l}4.3681^{* * *} \\
(1.0218)\end{array}$ & & $\begin{array}{c}1.9632 \\
(1.4009)\end{array}$ \\
\hline $\begin{array}{l}\text { Pure strategy } \\
\text { w/o pure structures/HRM/ICT }\end{array}$ & $\begin{array}{c}1.3424 \\
(0.8301)\end{array}$ & $\begin{array}{l}3.2392^{* *} \\
(1.3687)\end{array}$ & $\begin{array}{c}4.1359 * * * \\
(1.1560)\end{array}$ & $\begin{array}{c}0.8946 \\
(1.2456)\end{array}$ & & $\begin{array}{c}0.1198 \\
(1.0549)\end{array}$ & $\begin{array}{c}2.1176 \\
(1.5511)\end{array}$ & $\begin{array}{c}2.4048^{*} \\
(1.3850)\end{array}$ & $\begin{array}{l}-1.9632 \\
(1.4009)\end{array}$ & \\
\hline No-emphasis strategy & & $\begin{array}{c}-0.8967 \\
(1.1159)\end{array}$ & & $\begin{array}{c}-3.2413^{* * *} \\
(1.1556)\end{array}$ & $\begin{array}{c}-4.1359^{* * *} \\
(1.1560)\end{array}$ & & $\begin{array}{c}-0.2872 \\
(1.2342)\end{array}$ & & $\begin{array}{c}-4.3681^{* * *} \\
(1.0218)\end{array}$ & $\begin{array}{l}-2.4048^{*} \\
(1.3850)\end{array}$ \\
\hline Further controls & & Industry, & lufacturing & or, and ye & dummies; col & y dummy; & vironmental c & dynamism miss & sing dummy & \\
\hline Firms & 258 & 258 & 258 & 258 & 258 & 302 & 302 & 302 & 302 & 302 \\
\hline Observations & 457 & 457 & 457 & 457 & 457 & 520 & 520 & 520 & 520 & 520 \\
\hline $\mathrm{R}^{2}$ & 0.63 & 0.63 & 0.63 & 0.63 & 0.63 & 0.52 & 0.52 & 0.52 & 0.52 & 0.52 \\
\hline
\end{tabular}

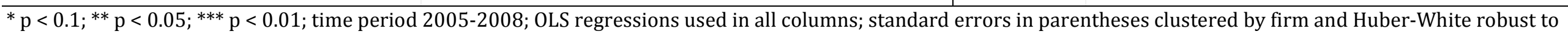
heteroskedasticity and autocorrelation of unknown form 